\title{
Circumscribing campo rupestre - megadiverse Brazilian rocky montane savanas
}

\author{
Alves, $R J V^{a *}$, Silva, $N$. $^{b}$, Oliveira, JA. ${ }^{c}$ and Medeiros, $D .^{a}$ \\ ${ }^{a}$ Departamento de Botânica, Museu Nacional, Universidade Federal do Rio de Janeiro - UFRJ, Quinta da Boa Vista, \\ s/n, São Cristóvão, CEP 20940-040, Rio de Janeiro, RJ, Brazil \\ bPrograma de Pós-graduação em Ciências Biológicas (Botânica), Museu Nacional, Universidade Federal do \\ Rio de Janeiro - UFRJ, Quinta da Boa Vista, s/n, São Cristóvão, CEP 20940-040, Rio de Janeiro, RJ, Brazil \\ ${ }^{\mathrm{C}}$ Departamento de Vertebrados, Museu Nacional, Universidade Federal do Rio de Janeiro - UFRJ, \\ Quinta da Boa Vista, s/n, São Cristóvão, CEP 20940-040, Rio de Janeiro, RJ, Brazil \\ *e-mail: ruyvalka@yahoo.com
}

Received: October 19, 2012 - Accepted: May 3, 2013 - Distributed: May 31, 2014

(With 1 figure)

\begin{abstract}
Currently campo rupestre (CR) is a name accepted and used internationally by botanists, zoologists, and other naturalists, usually applied to a very specific ecosystem, despite the lack of a consensual published circumscription. We present a tentative geographic circumscription of the term, combining data on climate, geology, geomorphology, soil, flora, fauna and vegetation. The circumscription of campo rupestre proposed herein is based on the following premises: (1) the classification of vegetation is not an exact science, and it is difficult to attain a high degree of consensus to the circumscription of vegetation names; (2) despite this, vegetation classification is useful for conservation and management. It is thus desirable to circumscribe vegetation types with the greatest attainable precision; (3) there is a need to preserve all montane and rocky vegetation types, regardless of classification, biome, etc; (4) the $C R s$ are formed by a complex mosaic of vegetation types including rock-dwelling, psammophilous, aquatic, epiphytic, and penumbral plant communities. Campos rupestres stricto sensu are a Neotropical, azonal vegetation complex endemic to Brazil, forming a mosaic of rocky mountaintop "archipelagos" inserted within a matrix of zonal vegetation, mainly in the Cerrado and Caatinga provinces of the Brazilian Shield (southeastern, northeastern and central-western regions), occurring mainly above $900 \mathrm{~m}$ asl. up to altitudes exceeding $2000 \mathrm{~m}$, having measured annual precipitation between 800 and $1500 \mathrm{~mm}$, and an arid season of two to five months.
\end{abstract}

Keywords: rocky savana, montane savana, rock-dwelling vegetation, biogeographic elements, vegetation classification, Neotropics.

\section{Circunscrevendo campo rupestre - savanas montanas rochosas megadiversas do Brasil}

\section{Resumo}

Atualmente campo rupestre (CR) é um termo aceito e internacionalmente usado por botânicos, zoólogos e outros naturalistas, geralmente aplicado a um ecossistema muito específico apesar de não haver uma circunscrição de consenso. Nós apresentamos uma ciscunscrição geográfica tentativa do termo, combinando dados de clima, geologia, geomorfologia, solo, flora, fauna e vegetação. A circunscrição de campo rupestre aqui proposta se baseia nas seguintes premissas: (1) a classificação da vegetação não é uma ciência exata e é difícil atingir um alto grau de consenso sobre a circunscrição de nomes de vegetação; (2) apesar disto, a classificação da vegetação é útil para conservação e manejo. Assim é desejável descrever os tipos de vegetação com a maior precisão tangível; exista a necessidade de se preservar todos os tipos de vegetação montanos e rochosos, independentemente de sua classificação, bioma, etc. (4) os $C R s$ são formados por um complexo mosaico de tipos de vegetação incluindo comunidades sobre rocha, psamíóilas, aquáticas, epífitas e penumbrais. Os campos rupestres stricto sensu são um complexo de vegetação endêmico ao Brasil, azonal, Neotropical, inserido numa matriz de vegetação zonal, sobretudo nas províncias do Cerrado e da Caatinga do Escudo do Brasil (regiões Sudeste, Nordeste e Centro_Oeste), ocorrendo principalmente acima de $900 \mathrm{~m}$ de altitude, até altitudes superiores a $2000 \mathrm{~m}$, tendo uma precipitação anual mensurada entre 800 e $1500 \mathrm{~mm}$, e uma estação árida de dois a cinco meses.

Palavras-chave: savana pedregosa, savana montana, vegetação sobre rocha, elementos biogeográficos, classificação da vegetação, Neotrópico. 


\section{Introduction}

Since the early 1990 s, the importance of mountains has been gaining broader international recognition within the framework of the Convention o Biological Diversity (Messerli and Ives, 1997). In Brazil, this recognition by the State arrived with some delay (Martinelli, 2007). Historically, Brazilian mountaintop vegetation with prevalent herbaceous and subshrub cover overlying outcrops and litholic soils was called campos alpinos (alpine fields) by (Sampaio, 1938). Subsequent authors called them "savanas de altitude" (altitudinal savannas), "campos de altitude" (altitudinal fields - for a definition see Vasconcellos, 2011), "campos quartzíticos" (quartzitic fields - tentatively circumscribed by Rizzini, 1979), “campo sujo" (dirty fields), “campo limpo" (clean fields), "campo úmido” (humid fields), "cerrado rupestre" (rupestrian fields), "carrasco" etc. Most of the aforementioned terms have not been circumscribed in detail, neither floristically nor physiognomically. This is also true for the term "campos rupestres' (henceforth CRs), coined by the botanist Magalhães (1966) to substitute the aforementioned older names applied to Brazilian open mountaintop vegetation. The latter term gained broader use in Brazilian botanical literature since the 1970s, especially in publications by researchers from the University of São Paulo (USP) in collaboration with Kew Gardens, which have applied it to continental montane vegetation restricted to Brazil, occurring mainly in the States of Minas Gerais, Bahia, and Goiás.

Currently campo rupestre is accepted and used internationally by botanists, zoologists, and other naturalists, despite the lack of a consensual published circumscription. A more detailed basis for such a circumscription was presented by Giulietti (1997) emphasising a richness of ca. 4,000 vascular plant species distributed on 6,000 to $7,000 \mathrm{~km}^{2}$, but the geographic emphasis was placed on the Espinhaço range, leaving out outliers (e.g. comparable formations in Goiás and Tocantins States).

In the classification proposed by Walter (1985), montane vegetation complexes including the CRs are azonal vegetation, being shaped mainly by edaphic factors with less influence from the macroclimate (Alves et al., 2007; Alves and Kolbek, 2010b). Unlike the zonal ecorregions determined by macroclimate, montane vegetation complexes including the CRs form a mosaic of mountaintop vegetation "islands". This insularity (Prance, 1994) is ancient: these mountains have not been in contact during the life history of their floras, hence individual CRs, even in geographically close localities, can share similar vegetation physiognomies, substrate types and microclimates, but have very low floristic similarities (Alves and Kolbek, 2010b).

In this paper, we provide a review of the ecological characteristics of Brazilian CRs, and of their present state of conservation. We briefly characterise the vegetation type and its variability, identify cases of endemism of flora and fauna, and the main ecological factors responsible for $\mathrm{CR}$ biodiversity, and initiate a discussion on biodiversity conservation of CRs. As most research has been conducted in the states of Minas Gerais and Bahia, which together harbour over $90 \%$ of the CRs, much of the available data is from those states, while the characteristics of other CRs (e.g. from. Goiás and Tocantins) are poorly known.

\section{Premises}

Our contribution to the circumscription of campo rupestre provided herein is based on the following premises: (1) the classification of vegetation is not an exact science, and it is difficult to attain a high degree of consensus to the circumscription of vegetation names; (2) vegetation classification is useful for conservation and management. It is thus desirable to circumscribe vegetation types with the greatest attainable precision; (3) there is a need to preserve all montane and rocky vegetation types, regardless of classification, ecorregion, etc; (4) the CRs are formed by a complex mosaic of vegetation types including rock-dwelling, psammophilous, aquatic, paludicolous, epiphytic, and penumbral plant communities. (5) the term CRs is most precisely applicable to the vegetation of the Espinhaço chain and outliers with the same lithology, restricted to continental Brazil, as defined by researchers from University of São Paulo, Kew Gardens, and their followers in publications, lectures and seminars over the last three decades.

\section{Circumscription and Discussion}

Campos rupestres stricto sensu are a Neotropical, azonal vegetation complex endemic to Brazil, forming a mosaic of rocky mountaintop "archipelagos" (Prance, 1994) inserted within a matrix of zonal vegetation, mainly in the Cerrado and Caatinga vegetation domains (Figure 1) of the Brazilian Shield in the southeastern, northeastern and central-western regions, usually in altitudes from 900 to over $2000 \mathrm{~m}$ asl.

The eastern limit of distribution of the CRs seems to be determined by the seasonal climate (over $100 \mathrm{Km}$ from the Atlantic coast) as opposed to the oceanic climate predominant on mountaintops closer to the coast, which harbor the campos de altitude (Safford, 1999a, b, 2001, 2007; Vasconcellos, 2011).

The northern limit of the CRs $\left(\sim 10^{\circ} \mathrm{S}\right)$ seems to be determined by distribution of the scarce annual rainfall (less than $650 \mathrm{~mm}$ ) where there are over five months with no precipitation. From northern Minas Gerais through Bahia, the only Brazilian cactoid Euphorbiaceae, represented by a few species which grow exclusively in the CRs, indicate this limit. The Serra da Capivara range in Piauí has the appropriate lithology, but the summit vegetation is a sclerophyllous scrub, and only one species occuring at the scrub edges is allied to the CR floristic element: Nanuza luetzelburgii R. J. V. Alves.

The southern limit of the CRs $\left(\sim 21,5^{\circ} \mathrm{S}\right)$ is roughly coincident with the Tropic of Capricorn, which is also roughly the transition between the Cerrado (north) and the "zona da mata" vegetation (forest zone) of Minas Gerais state. There are still typical CRs on the Ibitipoca range 


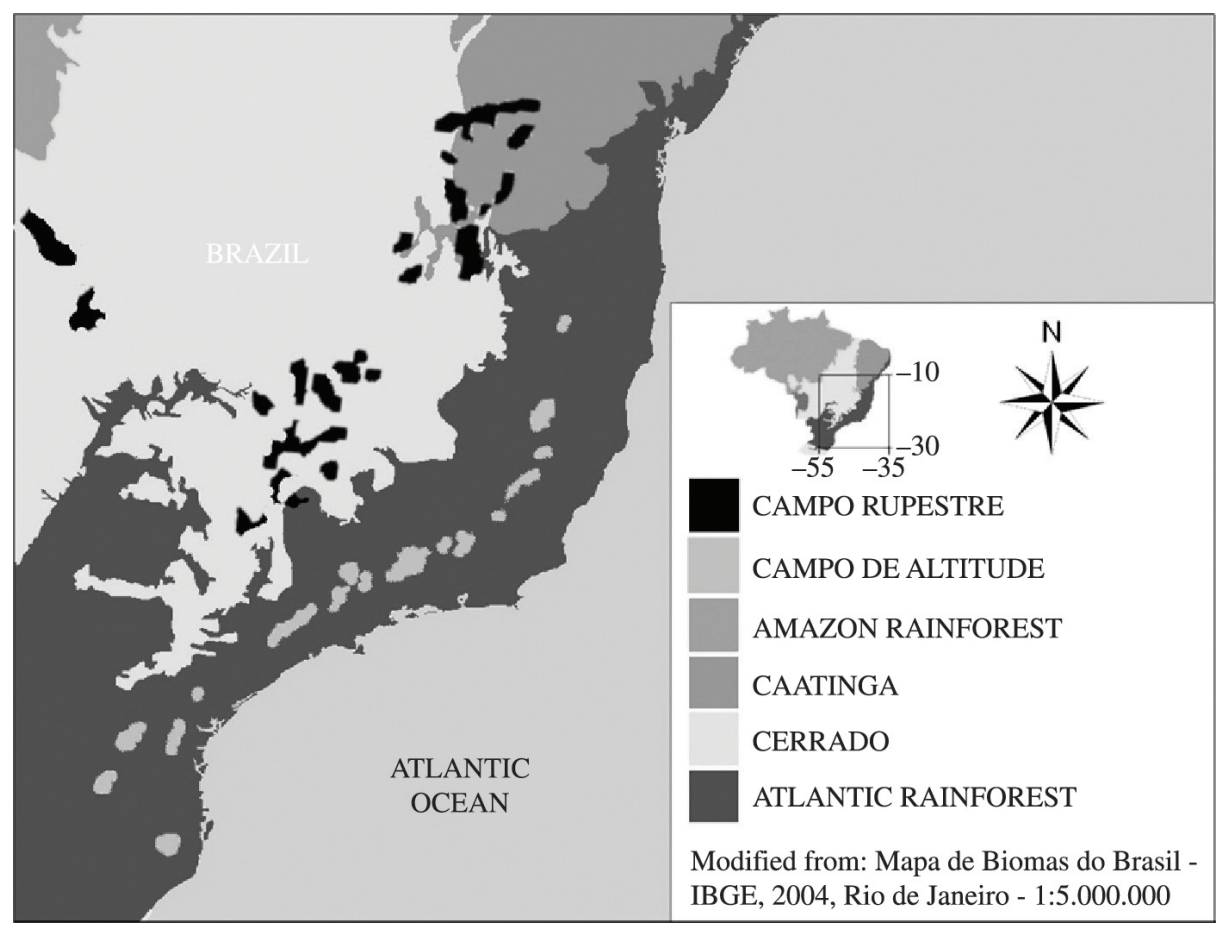

Figure 1. Mosaic showing main outcrop massifs inserted in zonal ecorregions of Eastern and Central Brazil.

(quartzite, $21,7^{\circ} \mathrm{S}, 43,8^{\circ} \mathrm{W}$ in contact with Cerrado), but in the Serra Negra range within the Atlantic forest (also quartzite, $22^{\circ} \mathrm{S}, 43.8^{\circ} \mathrm{W}$ just $35 \mathrm{Km}$ south of Ibitipoca), a woody scrub substitutes the natural open vegetation in most parts, and the open parts have more floristic elements of the campos de altitude, with Chusquea riosaltensis L. G. Clark dominating large extensions. Dominance of Chusquea, a typical element of campo de altitude, advocates for more abundant and better-distributed precipitation in Serra Negra, inserted in the forest zone rather than the savanna. On the Morro do Forno (state of São Paulo, $22^{\circ}$ $\mathrm{S}$, precipitation of $1517 \mathrm{~mm} /$ year), Oliveira and Godoy (2007) found several floristic elements typical of the CRs, such as Cambessedesia DC., Marcetia DC., Barbacenia Vand., Vellozia Vand., Xyris L. and Dicranopteris linearis (Burm. f.) Underw. The south Brazilian Campos occur in a subtropical region with hot summers, cool winters and no dry season, within the Pampa and Atlantic Forest Domains, and are floristically unrelated to the CRs (Overbeck et al., 2007).

The western limits of the CRs are yet to be established, by seeking more precise floristic, vegetation, climate and geological data from localities such as the Ricardo Franco range in Mato Grosso State, where preliminary botanical collections revealed some promising materials (Paulo G. Windisch, pers. comm.)

The climate in the zone where CRs occur is continental, with measured annual precipitation above $800-1500 \mathrm{~mm}$, with an arid season lasting two to five months. However, horizontal precipitation (which usually is not measured by meteorological stations) is copious, hence the plants in the
CRs have a daily water supply greater than that indicated for their zonal ecorregions. The CRs have pronounced oscillations between day and night temperatures (Alves, 1992). This markedly seasonal climate separates the CRs from other Neotropical open outcrop and montane formations which lack an arid season, such as the aforementioned campos de altitude and the Tepuis of the Amazon region.

The underlying outcrops of the CRs are metamorphic, mainly Precambrian quartzites exposed since the Tertiary and frequently also ironstone (hematite). The presence of CRs on other lithologies has not been confirmed.

The soils, when present, form a shallow layer of white sand, often darkened by charcoal from savanna fires, rarely reaching three meters in depth, overlying the bedrock. The water table in these soils suffers considerable seasonal fluctuations. These highly acidic, clayless and siltless soils are a true chemical desert with a considerable lack of nutrients, and the genus Philcoxia (Plantaginaceae) is endemic to three disjunct areas of CRs where it grows exclusively on these white sands (Taylor et al., 2000). The decomposition of organic matter in these soils is slow (Benites et al., 2003; Silva et al., 2004). Gravel, mainly composed of milky-quartz, is common in the CRs and several plant species such as Drosera schwackei (Diels) Rivadavia are restricted to it (Rivadavia et al., 2003).

With this soil nutrient poverty, it is a paradox that $15-60 \%$ of the flora of the Cerrado are exclusively found in the CRs, which occupy less than $3 \%$ of the vegetation domain (respectively Sano et al., 2008; Sano and De Almeida, 1998). The species richness per area of the CRs is also exponentially greater than in the zonal ecorregions 
in which they occur (Table 1), e.g. in the Caraça range, above 1,800 $\mathrm{m}$ asl., Oliveira (2010) found 356 species of flowering plants in an area of only $1 \mathrm{Km}^{2}$.

There is a high number of microendemisms in the CRs, with small populations restricted to single mountaintops: e.g. despite intense field efforts, in the São José range, only 15 individuals are known of Croton arlineae D. Medeiros, L. Senna \& R. J. V. Alves, and less than 50 of C. josephinus Müll. Arg. (Medeiros et al., 2002, 2008, 2011). Many species from the CRs are known only from a single collection (the holotype): e.g. in the Velloziaceae this is true for many species (Smith and Ayensu, 1976). Many genera are endemic to or reach their highest species diversity in the CRs (Harley, 1995; Giulietti and Pirani, 1988).

The largest Angiosperm families (Asteraceae, Orchidaceae, Poaceae, and Leguminosae lato sensu) are very well represented in the CRs, but this is also true for many other open vegetation types, so their relative species richnesses are not of diagnostic use. On the other hand, the vascular floristic markers (genera and species), which seem typical for the CRs, do not necessarily occur together in all localities of the mosaic. Even at the genus level, CRs on distinct mountains are floristically dissimilar (Alves and Kolbek, 2010b). Eriocaulaceae, Velloziaceae, and Xyridaceae are exceptionally species-rich in the CRs (Harley, 1995; Giulietti and Pirani, 1988). Among the marker taxa, a group of terete-leaved species of the orchid genus Acianthera Scheidw., (in older literature listed under Pleurothallis R. Br. or Specklinia Lindl.) is also exclusive of the CRs, where it initiates primary succession on rock outcrops (Alves and Kolbek, 2000). Another typical species is the small bamboo Aulonemia effusa (Hack.) Mc-Clure (Poaceae), as pointed out by Rizzini (1979), which occurs restricted to the CRs from the Chapada Diamantina (Vianna and Filgueiras, 2008) southward all the way to the Serra de São José (Alves and Kolbek, 2009). Specialised communities with carnivorous plants, including several species of Droseraceae (e.g. Drosera camporupestris Rivadavia, D. graomogolensis T. R. S. Silva, D. tentaculata Rivadavia, D. schwackei Rivadavia and $D$. chrysolepis Taub.) are also only restricted to the CRs.

Many plant species previously considered typical of the CRs also grow in other vegetation types such as
Quaternary coastal strand restingas, campos de altitude and even in the surrounding zonal vegetation (Alves et al., 2007; Vasconcellos, 2011).

Despite the shallow soils, a large prpoportion of the CR vascular floras are represented by geophytes, chamaephytes, hemicryptophytes and nanophanerophytes with well developed underground systems such as lignotubers, or other Specialised storage and bud-bearing structures (Conceição and Pirani, 2005; Alves and Kolbek, 2010a). Clonal growth is a common trait in the CRs. Several types of underground systems are responsible for more than $50 \%$ of the plant biomass in the CRs. These bud banks are an adaptation to disturbance (Klimes ová and Klimeš, 2007) represented in the CRs by savanna fires and the arid season (Conceição and Pirani, 2005; Kolbek and Alves, 2008), and sometimes can guarantee an impressive longevity for some species (Alves et al., 2013).

Furthermore, rock outcrops provide safe sites against disturbance by fire (Müller et al., 2007).

Several unrelated subshrub species also converge either by an ericoid habit, by leaves congested at the branch apices, and by decussate phyllotaxis. Many plant species in the CRs are r-strategists (sensu Grime, 2001) with very slow growth rates. The longevity found in shrubby species of Vellozia stands out in this respect (Alves, 1994), indicating that the outcrop vegetation of the CRs is a special type of climax, and not an initial phase of succession (Rizzini, 1979).

The "naked" rock outcrops of the CRs commonly exhibit a striation of dark and light vertical bands resembling a barcode, formed by colonies of epilithic and endolithic Cyanobacteria and algae (Alves et al., 2002; De Sousa et al., 2006, 2007a, b). As these crusts are active in nitrogen fixation (Büdel et al., 2000, 2002, 2004; Porembski, 2007), they probably facilitate succession by rock-dwelling communities, such as cushions dominated by lichens, bryophytes and monocotyledonous mats such as species of Trilepis Nees and Acianthera Scheidweiler. (Alves and Kolbek, 2000; Safford and Martinelli, 2000). Natural cavities in quartzite or ironstone CRs harbour peculiar penumbral plant communities (Alves and Kolbek, 1993; Jacobi et al., 2007, 2008).

The cover of the herb and subshrub layers in the CRs is usually higher than $50 \%$, while the shrub and tree layers rarely reach $10 \%$. Due to the frequent strong winds and the

Table 1. Comparison of species richness per area in the $C R s$ and respective ecorregions.

\begin{tabular}{lccccc}
\hline \multicolumn{2}{c}{ Province } & \multicolumn{2}{c}{ Cerrado } & Caatinga & \\
\hline \multicolumn{1}{c}{ Vegetation } & entire vegetation & CRs/Serra do & CRs/Serra de São & entire vegetation & CRs/Pico das \\
complex/Place & domain & Cipó & José & domain & Almas \\
Area $\left(\mathrm{km}^{2}\right)$ & $2,000,000$ & 200 & 25 & 850,000 & 170 \\
No. of species & 12,000 & 1,854 & 1,258 & $\sim 2,000$ & 1,044 \\
Species $/ \mathrm{km}^{2}$ & 0.006 & 9.27 & 50.32 & 0.002 & 6.14 \\
Source & Sano et al. (2008) & Flora* & Alves and & Sampaio et al. & Stannard et al. \\
& & & Kolbek (2010b) & $(2002)$ & $(1995)$ \\
\hline
\end{tabular}

*The number of species of the Serra do Cipó flora was compiled from the initial checklist published by Giulietti et al. (1987), updated progressively from 102 papers in the Bol. Bot. Univ. São Paulo, published between 1987 and 2011 , listed at: http://www.revistas.usp.br/bolbot/search/titles?searchPage=2). 
unstable soils, trees in the CRs rarely attain heights above 6 $\mathrm{m}$ (Kolbek and Alves, 2008). The vegetation physiognomies in the CRs are dictated mainly by microtopography, exposition, and soil drainage .

In Canga (ironstone CRs), Jacobi et al. (2007) discerned the following microhabitats: exposed rock surfaces; rock pools; ephemeral small ponds; rock fissures; soil-filled depressions, steps and crevices; monocotyledonous mats; tree associations; and crust edges and cave entrances [penumbral communities sensu Alves and Kolbek (1993)]. Other subdivisions were proposed for the CR mosaic by Conceição and Pirani (2005) and Alves and Kolbek (2010b). Shrubby Vellozia spp. and Podocarpus lambertii Klotzsch ex Endl. in the CRs often harbour peculiar epiphytic communities (Souza Werneck and Do Espírito Santo, 2002; Alves et al., 2008).

Strategic importance and conservation of the $C R s$

(1) A significant proportion of the floras within the Cerrado and Caatinga domains grows exclusively in the CRs;

(2) CRs capture rainwater and are responsible for redistribution of drinking water;

(3) CRs harbour many endemic animal species;

(4) CRs are a valuable natural scenery heritage.

Vertebrate endemics - As delimited here, CRs occur in island mountaintops and plateaus belonging to distinct parallel massifs oriented north to south across the hinterlands of the Brazilian shield, in the central portion of the diagonal of open formations that stretches from northeastern Brazil to northwest Argentina (Schmidt and Inger, 1951). The core region of CRs are found in the Espinhaço range, which extends from northern Bahia to southern Minas Gerais states, delimiting the east basin of Rio São Francisco, and the "Espigão Mestre" range, which encompasses several "serras" separating the Tocantins and São Francisco and Paraná river basins in east Goiás and west Bahia and Minas Gerais.

As would be expected, each of these river basins and mountain chains harbours endemic vertebrate species. Nevertheless, the current level of knowledge on the composition and distribution of the vertebrate faunas inhabiting mountaintops across this wide region is still incipient, and the condition of endemism is, for a number of cases, a hypothesis.

The Espinhaço range has been acknowledged as an important centre of endemism for anurans, lizards and birds (Rodrigues, 1987; Pugliese et al., 2004; Eterovick et al., 2005; Hayer, 1999, Nascimento et al., 2005; Rodrigues et al., 2005; Vanzolini, 1982), but at least for birds the endemic species seem to be better classified as "montane openhabitat endemics" - species endemic to the open-habitats of southeastern Brazilian mountaintops (campos rupestres and campos de altitude), including those restricted to campos rupestres" (Vasconcellos and Rodrigues, 2010). Hayer (1999) argued that, unlike what is observed in plants and other vertebrates, the endemic anuran fauna of CRs in the Espinhaço range shows a much stronger biogeographical affinity with the Atlantic forest than with the diagonal of open formations (caatinga - cerrado - gran chaco).

As for the mammals, most species inhabiting CRs are ordinarily found in other vegetation complexes in the Cerrado matrix such as the Cerrado sensu stricto (e.g., Pereira and Geise, 2009), but a few select taxa seem to be endemic or at least rarely recorded elsewhere. Mammal species possibly endemic of the CRs are usually restricted to one or a few mountain ranges of the same massif. Very rarely such species are found disjunct on CRs and mountains of far apart massifs, which indicates that they are restricted to this vegetation complex. Thus far, due to the insufficiency of faunistic inventories, it seems that such species are usually restricted to mountains or massifs with CRs, but not necessarily exclusive of the CRs. The only case of a mammal known exclusively from CRs is Olygoryzomys rupestris Weksler \& Bonvicino, 2005, a sigmodont rodent that has been recorded so far only in widely isolated localities: Alto Paraíso, Goiás, Chapada dos Veadeiros, in Goiás state, and two scattered localities in the Chapada Diamantina, northern Espinhaço range, state of Bahia. So far this species has only been captured at high altitudes $(1500 \mathrm{~m})$ either in CRs or on their limits with adjacent vegetation (Weksler and Bonvicino, 2005; Pereira and Geise, 2009).

Impacts - Extensive cattle grazing causes by far the largest and most widespread negative impact to the biodiversity of the CRs, even those within all formally established conservation units. Cattle dung causes a nutrient invasion in the originally poor soils, which triggers invasions by c-strategist plants such as the African molasses grass (Melinis minutiflora P. Beauv), which ultimately outcompete and eliminate the native r-strategists, and connect previously isolated saxicolous vegetation stands during fires. Unfortunately, M. minutiflora is currently common to all CRs (Kolbek and Alves, 2008). The impacts of fire upon the CRs, on the other hand, depend on the periodicity. The flora of the CRs has many pyrophytes and species adapted to savanna fire, e.g. the aforementioned underground systems (Alves and Silva, 2011). Surface mining, especially of iron ore, is also greatly depleting the CRs in many areas with endemic species, especially in Minas Gerais (Jacobi et al., 2007).

\section{Final Comments}

(1) Despite their variability and disjunctions, the Brazilian CRs are a phytogeographic unit controlled by substrate, climate and floristic elements, distributed mainly in the states of Minas Gerais, Bahia, and Goiás; (2) effective conservation of most of the CRs (which occupy a total area which represents less than $3 \%$ of the respective vegetation domains) would preserve the populations of a great number of endemic and rare native plant species; (3) due to their insularity, the concept of ecological corridors cannot be applied to the CRs. Interconnecting these "islands" would pose great risks for the numerous endemic populations and lead to loss of biodiversity at all levels; (4) The distinction 
between CRs and the campos de altitude has been eloquently established by Vasconcellos (2011). However, further analyses of what is currently called campo de altitude shall probably separate the species-poor plant communities of higher altitudes such as the Itatiaia Plateau (with Andean and even temperate affinities) from the megadiverse and essentially Neotropical mountaintop vegetation currently lumped under the same name.

\section{References}

ALVES, RJV., KOLBEK, J. and BECKER, J., 2008. Vascular epiphyte vegetation in rocky savannas of southeastern Brazil. Nordic Journal of Botany, vol. 26, no. 1-2, p. 101-117. http:// dx.doi.org/10.1111/j.0107-055X.2008.00190.x.

ALVES, RJV. and KOLBEK, J., 1993. Penumbral Rock Communities in Campo Rupestre Sites in Brazil. Journal of Vegetation Science, vol. 4, no. 3, p. 357-366. http://dx.doi.org/10.2307/3235594.

ALVES, RJV., SILVA, NG., FERNANDES, AJ. Jr. and GUIMARÃES, AR., 2013. Longevity of the Brazilian underground tree Jacaranda decurrens Cham. Anais da Academia Brasileira de Ciências, vol. 85, no. 2, p. 671-677. PMid:23828362. http:// dx.doi.org/10.1590/S0001-37652013005000038

-, 2000. Primary succession on quartzite cliffs in Minas Gerais, Brazil. Biologia, vol. 1, no. 55, p. 69-83.

-, 2009. Summit vascular flora of the Serra de São José, Minas Gerais, Brazil. Check List, vol. 5, no. 1, p. 35-73.

-, 2010a. Vegetation strategy of Vellozia crinita (Velloziaceae). Biologia, vol. 65, no. 2, p. 254-264. http://dx.doi.org/10.2478/ s11756-010-0005-y

-, 2010b. Can campo rupestre vegetation be floristically delimited based on vascular plant genera? Plant Ecology, vol. 207, no. 1, p. 67-79. http://dx.doi.org/10.1007/s11258-009-9654-8.

ALVES, RJV. and SILVA, N., 2011. O Fogo é Sempre um Vilão nos Campos Rupestres? Biodiversidade Brasileira, vol. 1, no. 2, p. $120-127$.

ALVES, RJV., 1992. The flora and vegetation of the Serra de São José in Minas Gerais, Brazil. Botanical Institute - Czechoslovak Academy of Sciences. 116 p. PhD Thesis.

-,, 1994. Morphological Age Determination \& Longevity in some Vellozia Populations in Brazil. Folia Geobotanica et Phytotaxonomica, vol. 29, no. 1, p. 55-59. http://dx.doi.org/10.1007/ BF02807775.

ALVES, RJV., CARDIN, L. and KROPF, MS., 2007. Angiosperm Disjunction "Campos Rupestres - Restingas" - a Re-evaluation. Acta Botanica Brasilica, vol. 21, no. 3, p. 675-685. http://dx.doi. org/10.1590/S0102-33062007000300014.

ALVES, RJV., MENEZES, M. and DE SOUZA, CA., 2002. An endolithic \& epilithic algal community in continental cliff quartzite in Minas Gerais, Brazil. Abstracts. In Symposium of the International Association for Vegetation Science, 2002. Porto Alegre. p. 33. Session B.

BENITES, VM., CAIAFA, AN., MENDONÇA, E. S., SCHAEFER, CE. and KER, JC., 2003. Solos e vegetação nos complexos rupestres de altitude da Mantiqueira e do Espinhaço. Floresta e Ambiente, vol. 10, no. 1, p. 76-85.
BÜDEL, B., BECKER, U., FOLLMANN, G. and STERFLINGER, K., 2000. Algae, fungi, and lichens on inselbergs. In POREMBSKI, S. and BARTHLOTT, W. (Eds.). Inselbergs: Biotic Diversity of Isolated Rock Outcrops in Tropical and Temperate Regions. Berlim: Springer. p. 69-90. Ecological Studies; 146.

BÜDEL, B., WEBER, B., KÜHL, M., PFANZ, H., SÜLTEMEYER, D. and WESSELS, D., 2004. Reshaping of sandstone surfaces by cryptoendolithic cyanobacteria: bioalkalization causes chemical weathering in arid landscapes. Geobiology, vol. 2, no. 4, p. 261268. http://dx.doi.org/10.1111/j.1472-4677.2004.00040.x.

BÜDEL, B., WEBER, HM., POREMBSKI, S. and BARTHLOTT, W., 2002. Cyanobacteria of inselbergs in the Atlantic rainforest zone of eastern Brazil. Phycologia, vol. 41, no. 5, p. 498-506. http://dx.doi.org/10.2216/i0031-8884-41-5-498.1.

CONCEIÇÃO, AA. and PIRANI, JR., 2005. Delimitação de habitats em campos rupestres na Chapada Diamantina, Bahia: substratos, composição florística e aspectos estruturais. Boletim de Botânica da Universidade de São Paulo, vol. 23, no. 1, p. 85-111.

DE SOUSA, VLM., ALVES, RJV., MENEZES, M., SANT'ANNA, CL. and ALVES, CA., 2006. Endolithic cyanobacteria: extremophiles in quartzite outcrops. In: Brazilian Workshop on Astrobiology. Rio de Janeiro. p. 13. v. 1.

DE SOUSA, VLM., MENEZES, M. and ALVES, RJV., 2007a. Morphology and Life Cycle of Chlorohyta Species Isolated from Termite Mounds on Continental Quartzite, Brazil. In Abstracts of the 5th International Symposium "Biology and Taxonomy of Green Algae", 2007a.

-, 2007b. Morphology and Life Cycle of Chlorohyta Species Isolated from Termite Mounds on Continental Quartzite, Brazil. Phycological Section of the Slovak Botanical Society \& Slovak Academy of Sciences, Bratislava; Institute of Botany, Slovak Academy of Sciences, Bratislava \& Faculty of Natural Sciences, Comenius University, Bratislava. Congress Center of the Slovak Academy of Sciences, Smolenice-Castle, Slovakia.

DE SOUSA, VLM., MENEZES, M., DE SOUZA, CA., SANT'ANNA, CL. and ALVES, RJV., 2006a. Biodiversidade de cianobactérias cocóides epilíticas e endolíticas em afloramentos rochosos da Serra de São José, MG. In Congresso Brasileiro de Ficologia, Simpósio Latino Americano sobre Algas Nocivas, 2006. Itajaí: UNIVALI. p. 146. v. 1.

ETEROVICK, PC., DE QUEIROZ CARNAVAL, ACO., BORGESNOJOSA, DM., SILVANO, DL., SEGALLA, MV. and SAZIMA, I., 2005. Amphibian Declines in Brazil: An Overview. Biotropica, vol. 37, no. 2, p. 166-179. http://dx.doi.org/10.1111/j.17447429.2005.00024.x.

GIULIETTI, AM. and PIRANI, JR., 1988. Patterns of geographic distribution of some plant species from the Espinhaço Range, Minas Gerais and Bahia, Brazil. - In: VANZOLINI, PE. and HEYER, WR. (Eds.). Proceedings of a workshop on neotropical distribution patterns. Rio de Janeiro: Academia Brasileira de Ciências. p. 39-69.

GIULIETTI, AM., MENEZES, NL., PIRANI, JR., MEGURO, M. and WANDERLEY, MGL., 1987. Flora da Serra do Cipó, Minas Gerais: Caracterização e lista das espécies. Boletim de Botânica da Universidade de São Paulo, vol. 9, p. 1-151.

GIULIETTI, AM., 1997. Espinhaço Range Region, Eastern Brazil. In: DAVIS, SD. and HEYWOOD, VH. (Eds.). Centres of Plant 
Diversity - a Guide and Strategy for their Conservation. World Conservation Union. 578 p.

GRIME, JP., 2001. Plant strategies, vegetation processes, and ecosystem properties. -2 nd ed. John Wiley, Sons Ltd, Chichester. $417 \mathrm{pp}$.

HARLEY, RM., 1995. Introduction. In STANNARD, B.L., HARVEY, YB. and HARLEY, RM. (Eds.). Flora of the Pico das Almas, Chapada Diamantina - Bahia, Brazil. London: Royal Botanic Gardens, Kew, p. 1-40.

HAYER, R., 1999. A new genus and species of frog from Bahia, Brazil (Amphibia:Anura: Leptodactylidae) with comments on the zoogeography of the Brazilian campos rupestres. Proceedings of the Biological Society of Washington, vol. 112, no. 1, p. 19-39.

JACOBI, CM. and FONSECA DO CARMO, F., 2008. The contribution of ironstone outcrops to plant diversity in the Iron Quadrangle, a threatened Brazilian landscape. Ambio, vol. 37, no. 4, p. 324-326. http://dx.doi.org/10.1579/0044-7447(2008)37[324:TC OIOT]2.0.CO;2. PMid:18686515

JACOBI, CM., CARMO, FF., VINCENT, RC. and STEHMANN, JR., 2007. Plant communities on ironstone outcrops: A diverse and endangered Brazilian ecosystem. Biodiversity and Conservation, vol. 16 , no. 7 , p. 2185-2200. http://dx.doi.org/10.1007/s10531007-9156-8.

KLIMEŠOVÁ, J. and KLIMEŠ, J., 2007. Bud banks and their role in vegetative regeneration - A literature review and proposal for simple classification and assessment. Perspectives in Plant Ecology, Evolution and Systematics, vol. 8, no. 3, p. 115-129. http://dx.doi.org/10.1016/j.ppees.2006.10.002.

KOLBEK, J. and ALVES, RJV., 2008. Impacts of cattle, fire and wind in rocky savannas, Souteastern Brazil. Acta Universitatis Carolinae Environmentalica, vol. 22, p. 111-130.

MAGAlHÃES, GM., 1966. Sobre os Cerrados de Minas Gerais. Anais da Academia Brasileira de Ciencias, suplemento, p. 59-70.

MARTINELLI, G., 2007. Mountain biodiversity in Brazil. Revista Brasileira de Botânica. vol. 30, no. 4, p. 587-597.

MEDEIROS, D., ALVES, RJV. and DE SENNA-VALLE, L., 2011. Rediscovery of Croton josephinus (Euphorbiaceae) in Minas Gerais, Brazil. Edinburgh Journal of Botany, vol. 68, no. 01, p. 33-38. http://dx.doi.org/10.1017/S0960428610000259.

MEDEIROS, D., DE SENNA-VALLE, L. and ALVES, RJV., 2002. Espécie nova de Croton L. (Euphorbiaceae) do estado de Minas Gerais, Brasil. Bradea, vol. 8, p. 299-302.

MEDEIROS, D., DE SENNA-VALLE, L. and ALVES, RJV., 2008. Euphorbiaceae nativas de cerrado e campo rupestre da Serra de São José, Minas Gerais, Brasil. Arquivos do Museu Nacional, vol. 66 , no. 2 , p. 323-349

MESSERLI, B. and IVES, JD., 1997. Mountains of the WorldA Global Priority. A Contribution to Chapter 13 of Agenda 21. New York: Parthenon Publ. Group. 495 p.

MÜLLER, SC., OVERBECK, GE., PFADENHAUER, J. and PILLAR, VD., 2007. Plant functional types of woody species related to fire disturbance in forest-grassland ecotone. Plant Ecology, vol. 189, no. 1, p. 1-14. http://dx.doi.org/10.1007/ s11258-006-9162-z.

NASCIMENTO, LB., WACHLEVSCKI, M. and LEITE, F., 2005. Anuros. In: SILVA, AC., PEDREIRA, LCVSF. and ABREU, PA.
(Eds.). Serra do Espinhaço Meridional: paisagens e ambientes. Belo Horizonte: Ed. O Lutador. p. 210-229.

OLIVEIRA, C.T., 2010. Flora do complexo rupestre altomontano da Serra do Caraça e suas relações fitogeográficas. Instituto de Ciências Biológicas, UFMG. Dissertação de Mestrado.

OLIVEIRA, RB. and GODOY, SAP., 2007. Composição florística dos afloramentos rochosos do Morro do Forno, Altinópolis, São Paulo. Biota Neotropica, vol. 7, no. 2, p. 37-48. http://dx.doi. org/10.1590/S1676-06032007000200004.

OVERBECK, GE., MÜLLER, SC., FIDELIS, A., PFADENHAUER, J., PILLAR, VD., BLANCO, CC., BOLDRINI, II., BOTH, R. and FORNECK, ED., 2007. Brazil's neglected biome: The South Brazilian Campos. Perspectives in Plant Ecology, Evolution and Systematics, vol. 9, no. 2, p. 101-116. http://dx.doi.org/10.1016/j. ppees.2007.07.005.

PEREIRA, LG. and GEISE, L., 2009. Non-flying mammals of Chapada Diamantina (Bahia, Brazil). Biota Neotroica, vol. 9, no. 3, p. 185-196. http://dx.doi.org/10.1590/S1676-06032009000300019.

POREMBSKI, S., 2007. Tropical inselbergs: habitat types, adaptive strategies and diversity patterns. Revista Brasileira de Botânica, vol. 30 , no. 4 , p. $579-586$.

PRANCE, GT., 1994. A Comparison of the Efficacy of Higher Taxa and Species Numbers in the Assessment of Biodiversity in the Neotropics. Philosophical Transactions of the Royal Society of London. Series B, Biological Sciences, vol. 345, no. 1311, p. 89-99. http://dx.doi.org/10.1098/rstb.1994.0090.

PUGLIESE, A., POMBAL, JP Jr. and SAZIMA, I., 2004. A new species of Scinax (Anura: Hylidae) from rocky montane fields of the Serra do Cipó, Southeastern Brazil. Zootaxa, vol. 688, p. 1-15.

RIVADAVIA, F., KONDO, K., KATO, M. and HASEBE, M., 2003. Phylogeny of the sundews, Drosera (Droseraceae), based on chloroplast rbcL and nuclear $18 \mathrm{~S}$ ribosomal DNA Sequences. American Journal of Botany, vol. 90, no. 1, p. 123-130. http:// dx.doi.org/10.3732/ajb.90.1.123. PMid:21659087

RIZZINI, CT., 1979. Tratado de Fitogeografia do Brasil. São Paulo: Editora da Universidade de São Paulo. 374 p. (Aspectos Sociológicos e Florísticos; vol. 2).

RODRIGUES, M., CARRARA, LA., FARIA, LP. and GOMES, HB., 2005. Aves do Parque Nacional da Serra do Cipó: o Vale do Rio Cipó, Minas Gerais, Brasil. Revista Brasileira de Zoologia, vol. 22 , no. 2 , p. 326-338. http://dx.doi.org/10.1590/S010181752005000200005 .

RODRIGUES, MT., 1987. Distribution of lizards of the genus Tropidurus in Brazil (Sauria, Iguanidae). VANZOLINI, PE. and HEYER, WR. (Eds.). In: Proceedings of a Workshop on Neotropical distribution patterns held. Rio de Janeiro: Academia Brasileira de Ciências. p. 305-315.

SAFFORD, HD. and MARTINELLI, G., 2000. Southeast Brazil. - In BARTHLOTT, W. and POREMBSKI, S. (Eds.). Inselbergs: Biotic Diversity of isolated rock outcrops in Tropical and Temperate regions. Berlin: Springer Verlag; New York: Heidelberg. p. 339-389.

SAFFORD, HD., 1999a. Brazilian Páramos II. Macro- and mesoclimate of the campos de altitude and affinities with high mountain climates of the tropical Andes and Costa Rica. Journal of Biogeography, vol. 26, no. 4, p. 713-737. http://dx.doi. org/10.1046/j.1365-2699.1999.00312.x.

-, 1999b. Brazilian Páramos I. An introduction to the physical environment and vegetation of the campos de altitude. Journal 
of Biogeography, vol. 26, no. 4, p. 693-712. http://dx.doi. org/10.1046/j.1365-2699.1999.00313.x.

-, 2001. Brazilian Paramos III. Patterns and Rates of Postfire Regeneration in the Campos de Altitude. Biotropica, vol. 33, no. 2 , p. 282-302.

-, 2007. Brazilian Páramos IV. Phytogeography of the campos de altitude. Journal of Biogeography, vol. 34, no. 10, p. 1701-1722. http://dx.doi.org/10.1111/j.1365-2699.2007.01732.x.

SAMPAIO, AJ., 1938. Phytogeografia do Brasil. São Paulo: Comp. Ed. Nac.

SAMPAIO, EVSB., GIULIETTI, AM., VIRGÍNIO, J. and GAMARRA-ROJAS, CFL., 2002. Vegetação e Flora da Caatinga. Recife: Associação Plantas do Nordeste e Centro Nordestino de Informações sobre Plantas (CNIP).

SANO, SM. and DE ALMEIDA, SP., 1998. Cerrado - ambiente e flora. Planaltina: Embrapa. 556 p.

SANO, SM., DE ALMEIDA, SP. and RIBEIRO, JF., 2008. Cerrado - Ecologia e Flora. Planaltina: Embrapa. 876 p.

SCHMIDT, KP. and INGER, RF., 1951. Amphibians and reptiles of the Hopkins-Branner expedition to Brazil. Fieldiana Zoology, vol. 31 , p. 439-465.

SILVA, AC., VIDAL-TORRADO, P., CORTIZAS, AM. and RODEJA, EG., 2004. Solos do topo da Serra de São José (Minas Gerais) e suas relações com o paleoclima no sudeste do Brasil. Revista Brasileira de Ciencia do Solo, vol. 28, no. 3, p. 455-466. http://dx.doi.org/10.1590/S0100-06832004000300007.

SMITH, LB. and AYENSU, ES., 1976. A Revision of American Velloziaceae. Smithsonian Contr. Bot., vol. 30, p. 1-172. http:// dx.doi.org/10.5479/si.0081024X.30.

SOUZA WERNECK, M. and DO ESPÍRITO-SANTO, MM., 2002. Species diversity and abundance of vascular epiphytes on Vellozia piresiana in Brazil. Biotropica, vol. 34, no. 1, p. 51-57. http://dx.doi.org/10.1111/j.1744-7429.2002.tb00241.x.
STANNARD, BL., HARVEY, YB. and HARLEY, RM. (Eds.). 1995. Flora of the Pico das Almas, Chapada Diamantina-Bahia, Brazil. London: Royal Botanic Gardens, Kew. 853 p.

TAYLOR, P., SOUZA, VC., GIULIETTI, AM. and HARLEY, RM., 2000. Philcoxia: A New Genus of Scrophulariaceae with Three New Species from Eastern Brazil. Kew Bulletin, vol. 55, no. 1, p. 155-163. http://dx.doi.org/10.2307/4117770.

VANZOLINI, PE., 1982. A new Gymnodactylus from Minas Gerais, Brasil, with remarks on the genus on the area and on montane endemisms in Brasil (Sauria, Gekkonidae). Papéis Avulsos de Zoologia, vol. 34, p. 403-413.

VASCONCELLOS, MF. and RODRIGUES, M., 2010. Patterns of geographic distribution and conservation of the open-habitat avifauna of southeastern Brazilian mountaintops (campos rupestres and campos de altitude). Papéis Avulsos de Zoologia (São Paulo), vol. 50, no. 1, p. 1-29. http://dx.doi.org/10.1590/ S0031-10492010000100001

VASCONCELLOS, MF., 2011. O que são campos rupestres e campos de altitude nos topos de montanha do Leste do Brasil? Revista Brasileira de Botânica, vol. 34, no. 2, p. 241-246.

VIANNA, PL. and FILGUEIRAS, TS., 2008. Inventário e distribuição geográfica das gramíneas (Poaceae) na Cadeia do Espinhaço, Brasil. Megadiversidade, vol. 4, no. 1-2, p. 71-88.

WALTER, H., 1985. Vegetation of the Earth and Ecological Systems of the Geobiosphere. New York: Springer-Verlag Berlin Heidelberg. 318 p.

WEKSLER, M. and BONVICINO, CR. 2005. Taxonomy of pigmy rice rats genus Oligoryzomys Bangs, 1900 (Rodentia, Sigmodontinae) of the Brazilian cerrado, with the description of two new species. Arquivos do Museu Nacional, vol. 63, no. 1, p. 113-130. 